Article

\title{
Properties of Mortars with Recycled Stone Aggregate for the Reconstruction of Sandstone in Historic Buildings
}

\author{
Beata Klimek ${ }^{1, *}$ and Małgorzata Grzegorczyk-Frańczak ${ }^{2}$ \\ 1 Department of Conservation and Built Heritage, Faculty of Civil Engineering and Architecture, \\ Lublin University of Technology, 20-618 Lublin, Poland \\ 2 Civil Engineering Laboratory, Faculty of Civil Engineering and Architecture, Lublin University of Technology, \\ 20-618 Lublin, Poland; m.grzegorczyk@pollub.pl \\ * Correspondence: b.klimek@pollub.pl
}

check for updates

Citation: Klimek, B.;

Grzegorczyk-Frańczak, M. Properties of Mortars with Recycled Stone Aggregate for the Reconstruction of Sandstone in Historic Buildings. Sustainability 2021, 13, 1386. https://doi.org/10.3390/su13031386

Academic Editors: José Ignacio Alvarez and Asterios Bakolas Received: 8 December 2020

Accepted: 22 January 2021

Published: 28 January 2021

Publisher's Note: MDPI stays neutral with regard to jurisdictional claims in published maps and institutional affiliations.

Copyright: (c) 2021 by the authors. Licensee MDPI, Basel, Switzerland. This article is an open access article distributed under the terms and conditions of the Creative Commons Attribution (CC BY) license (https:/ / creativecommons.org/licenses/by/ $4.0 /)$.

\begin{abstract}
The research concerned the mortars with recycled stone aggregate used for the reconstruction of historic objects. The face of stone walls is exposed to atmospheric, chemical, and biological factors, causing its destruction. The aim of the research was to develop a mortar that would be compatible with the stone both in terms of its external appearance as well as its physical and mechanical properties. For this purpose, three mortars based on recycled sandstone aggregate with three different gradations were prepared. The compatibility of stone and mortar was tested in terms of the physical and mechanical properties as well as the resistance to salt and frost corrosion. The mortars reflect the properties of sandstone and offer great opportunities to adjust them as desired. The frost resistance of the mortars was consistent, with practically no weight loss after 25 test cycles. They achieved lower compression strength than stone, which is an important feature in avoiding destruction by using an excessively strong mortar. Moreover, the absorbability of the mortars turned out to be favorable (max. $25 \%$ ). Mortars were resistant to the destructive effect of salt and did not show the ability to whitewash and desalinate.
\end{abstract}

Keywords: natural stone; recycling; mineral mortars; durability; compatibility; monuments

\section{Introduction}

A large group of historic buildings were constructed from stone as the main building material. Stone has also been used for decoration including architectural details, bas-reliefs, cornices, supports, and columns. Out of the numerous types of rock used on historic façades, sandstone is especially prominent.

The damaging processes of historic buildings as well as their renovation have been the subject of numerous studies. This stems not only from the increased interest in global cultural heritage and its preservation, but is also connected with the accelerated degradation rate of façade materials caused by environmental pollution and climate change as well as the application of incompatible materials for renovation works [1,2].

Degradation of sandstone (Figure 1) depends both on internal and external factors. These include microstructural properties, density, hygroscopic properties, thermal expansion coefficient, elastic modulus, and compressive strength. The susceptibility of stone to the degradation factors is dependent on the environmental pollution, extreme environmental conditions, dampness, salinity, biological corrosion, and application of incompatible materials. It is also directly connected with the microstructural and mechanical properties of stone $[3,4]$. 


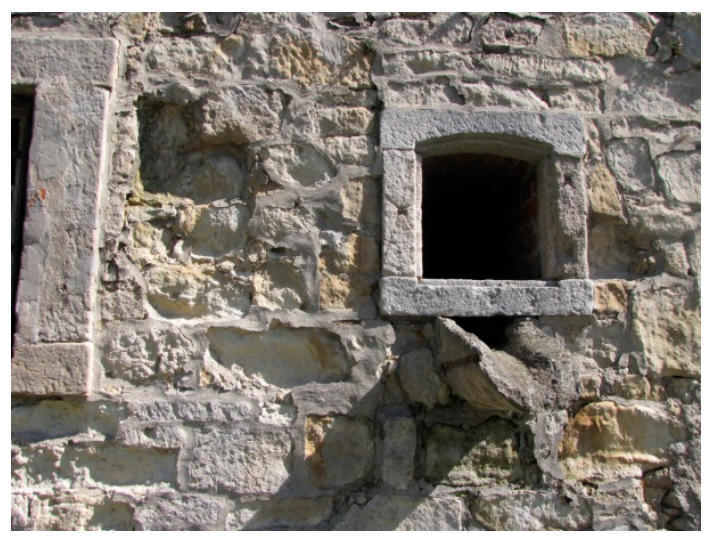

(a)

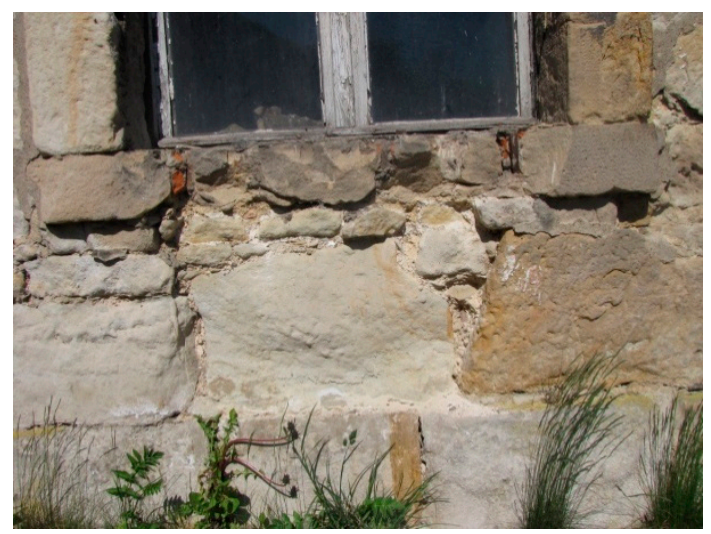

(c)

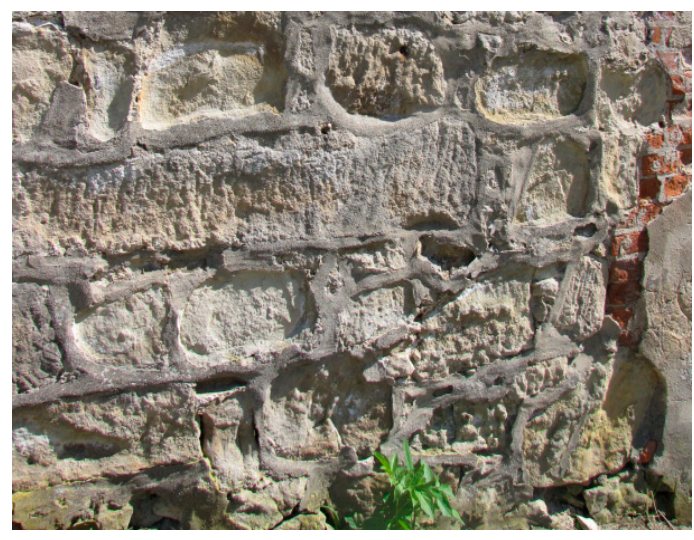

(b)

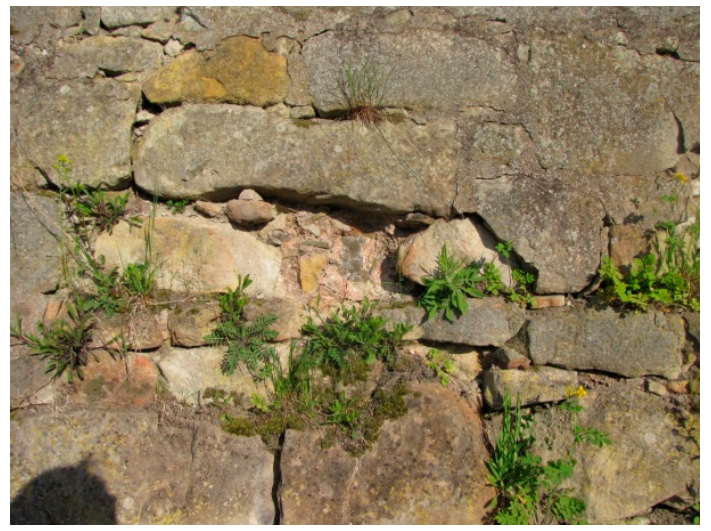

(d)

Figure 1. Degradation of natural stone: (a) Soil loss below sputters; (b) Stone erosion with well-preserved cement binder; (c) Salt crystallization on the stone surface; (d) Vegetation growing on walls.

Conservation of the sandstone façade is of key importance in preserving stone masonry structures. Numerous difficulties, connected with filling gaps or replacing stone, arise during renovation works, which mainly results from the limited availability of certain types of stone, the high costs of extraction and transport as well the impact of these actions on the environment.

As indicated by studies and practice, while selecting the sandstone required for conservation works, using the terms "szydłowiecki sandstone" or "radkowski sandstone" can be deceptive. This is because the sandstones (e.g., from the kłodzki region) are characterized by diversified grain pattern within the same deposit. Higher parts of the deposit may contain coarse-grained and very hard stone; the middle parts may contain mediumgrained and less hard stone; whereas the lowest parts contain fine-grained and moderately hard sandstone. Thus, batches of sandstone from the same excavation might differ from each other to a greater extent than the sandstone originating from a mine located several hundred kilometers away [5].

An environmentally friendly alternative is to use artificial stones that are designed in accordance with the guidelines and criteria based on the historical properties of materials [6].

A compatible renovation mortar is a conservation material that does not affect the local historic materials in any way, either directly or indirectly. Thus, it does not cause chemical changes in historic materials, does not initiate or aggravate the degradation phenomena, and ensures preservation of the historic stone material. The conducted studies are connected with devising a methodology aimed at facilitating the compatibility assessment through general hints and case studies, as well as determining the mismatch indices of renovation mortar properties in relation to the repaired surface [7-9]. 
By designing a mortar with the properties similar to a certain type of stone, a compatible, environmentally friendly product can be obtained at low cost using local resources. Renovation mortars are specially designed for each location; they have the appearance of natural stone as well as maintain durability and the possibility of adapting to the local environment with no side-effects [1,10].

Numerous investigations connected with designing new mortars also pertain to their compatibility in terms of the application in conservation works [9-14].

It has been shown that a renovation mortar cannot contain harmful compounds such as salts (e.g., calcium sulfate or sodium salts), which could negatively affect and-in the case of dampness-degrade the material [15].

In order to maintain stable and similar moisture content, renovation mortars should not increase capillary rise in the historic material [16].

The number of pores and their size ensure the appropriate microstructure of the mortar, which is connected with the transportation of moisture, which in turn affects the durability as well as resistance to salt and frost corrosion [17].

If compatibility is confirmed, maximum durability can be ensured, in addition to the possibility of using the mortar for further repairs.

The compatibility of the repair mortar is related, among other things, to the origin of the raw materials used in its production. "Green" mortars are made of recycled and renewable materials [18].

The processes of acquiring raw materials and mortar production are also assessed in terms of energy consumption and pollutants emitted in the process. The raw materials used in traditional mortars (e.g., calcium, pozzolanic materials, recycled natural stone aggregate) do not require a lot of energy for their production, leaving no residues to be disposed of. Moreover, in the era of increasingly popular sustainable development, it is important to seek alternative sources of natural aggregates [19-22]. High durability, characterizing the traditional mortars used in historical buildings and monuments, exposed to detrimental environmental factors contributes to the favorable outcome of life cycle assessment and to sustainable development.

In recent years, cement and polymer mortars, incompatible with historic building materials, have been widely employed in conservation works. Apart from causing damages to the historic material, they are also characterized by limited durability. The negative effect of incompatible renovation mortars is attributed to their physicochemical properties, which are different from the original building materials [1].

Kłodzko Fortress (Figures 2 and 3) constitutes one of the most important and prominent monuments of the Lower Silesian Voivodeship. The Fortress is located on Castle Hill (369 m a.s.l.) in the city center, occupying an area of over 30 ha. The object is inextricably connected with the history of Kłodzko city. In the 9th century, a wooden fortified gord was located in this place, whereas castellany was established within the fortress in the 12th century. Later on, the castle was turned into a mansion comprising dwellings, a chapel, and a church. In the mid-16th century, the fortress was expanded with lower and middle levels, which-together with the higher level and fortifications-comprised a large defensive system of the city. Further fortifications were created in 1690-1702. Kłodzko Fortress, similar to those in Koźle and Świdnica, was the largest stronghold in Silesia. Along with the changes in warfare, the role of these fortifications diminished until the end of the 18th century, when the expansion ceased. At present, Kłodzko Fortress is one of the most attractive military structures in Europe [23]. 


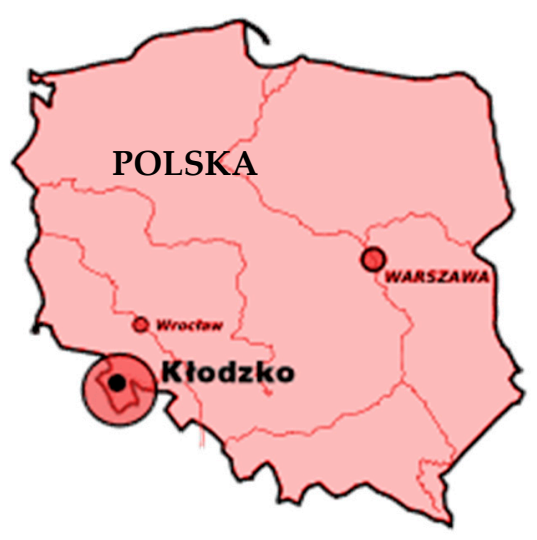

Figure 2. Location of Kłodzko on a map of Poland.

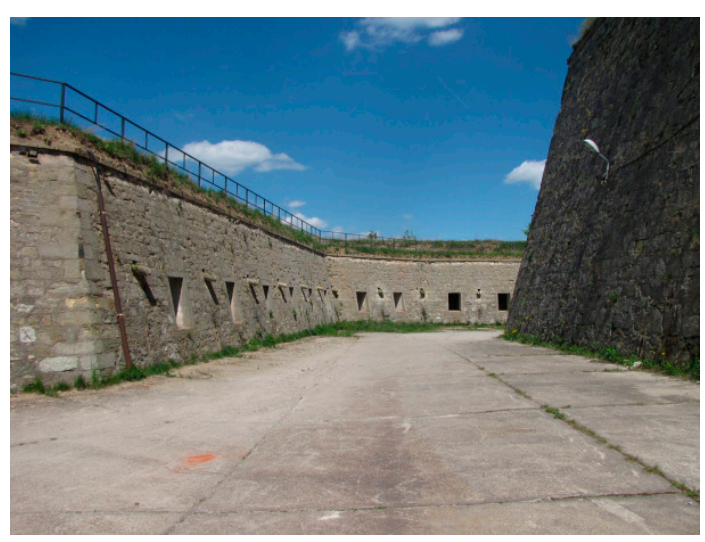

Figure 3. Fragment of the Kłodzko Fortress fortifications.

The studies conducted at Kłodzko Fortress indicate that the degradation of stone walls is connected with the application of mortars that were not compatible with the historic materials [24]. As has been reported in the research, the substantial degradation of the external faces of walls resulted from the presence of salt in the cement mortars used as a binder.

This paper presents three renovation mortars in order to select the most optimal and compatible one. By changing the aggregate fractions, efforts were made to obtain the mortars with the above-mentioned characteristics suitable for repairing stone with different grain size. The main criteria were the capillary properties of the mortars and their compressive strength. These two features mainly determine the durability of the stone-mortar connections. The mortar should have better capillary properties than the sandstones, so that it can act as a filter that draws water from the stones, and basically salt solutions. Thus, the mortar takes over the role of a buffer, protecting historic stones against destruction, while succumbing to it itself. In order for the mortar to fulfill its protective function, its mechanical strength should not be higher than that of sandstone. Weaker mortars will be more easily damaged than sandstones in the event of temperature fluctuations, water freezing and the action of water-soluble salts. On the basis of these studies, the recommendations pertaining to the preparation of a more compatible mortar, which could be employed during construction and renovation of monuments (e.g., Kłodzko Fortress) were formulated. Compared to previous studies, it is the first time that the aggregate has been completely replaced with sandstone aggregate, thus differentiating the fractions. For the first time in this type of study, a dye copolymer of vinyl acetate and methylcellulose with hydrophobic admixture was added as an additive. 


\section{Materials and Methods}

\subsection{Materials}

Three recipes of renovation mortar mixes were devised. As fine, medium, and coarsegrained squeaks occur at the fortress of Klodzko and they are subject to corrosion processes, repair mortars were designed with fine, medium, and coarse aggregates. Stratification is commonly (but not always) found in these stones; the stone is cut in a characteristic way, making it easy to divide into cuboids. Several types of sandstone, differing in age, structure, and environment in which they formed (noworudzki, radkowski, Szczytna sandstones), can be found in Kłodzko [24].

In order to obtain a mortar with relatively high strength and at the same time resilient and vapor-permeable, white cement CEM I 52.5 R and hydrated lime were used as binders. The admixtures improving the resistance to salt and low temperature of the cured product (vinyl acetate and methyl cellulose copolymer with hydrophobic admixture) were selected based on the research of one of the authors published in the previous article [25].

The mortar mixes were differentiated through the addition of heterogeneous aggregate (sandstone) fractions obtained by recycling the stone from the Fortress. The devised mortar mixtures were designated depending on their fractions: (M3) - coarse-grained mortar, (M1) - fine-grained mortar, (M2)_-medium-grained mortar. The composition of the mortars is presented in Table 1.

Table 1. Composition of mortar wt. (\%).

\begin{tabular}{cccc}
\hline Material & M1 & M2 & M3 \\
\hline Cement CEM I 52.5 R & 15.54 & 15.54 & 15.54 \\
Hydrated lime & 23.21 & 23.21 & 23.21 \\
Stone aggregate 0.1 $<$ SA $<0.25 \mathrm{~mm}$ & 60.20 & - & - \\
Stone aggregate $0.1<$ SA $<0.5 \mathrm{~mm}$ & - & 60.20 & - \\
Stone aggregate $0.1<$ SA $<1.0 \mathrm{~mm}$ & - & - & 60.20 \\
Methylcellulose & 0.15 & 0.15 & 0.15 \\
Copolymer of vinyl acetate-ethylene & 0.9 & 0.9 & 0.9 \\
\hline
\end{tabular}

A detailed description of the mortar components is as follows:

- CEM I 52.5 R Portland cement with the following properties: compressive strength after two days-31.6 MPa; compressive strength after 28 days-64.7 MPa; specific surface $-4571 \mathrm{~cm}^{2} / \mathrm{g}$; initial setting time $-160 \mathrm{~min}$; final setting time-210 $\mathrm{min}$; loss on ignition-2.77\%; whiteness-75\%; insoluble residue- $0.52 \%$; Cl content $-0.023 \%$.

CEM I 52.5 R Portland cement was studied in accordance with the EN 197-1 standard [26]. The chemical composition of the cement is provided in Table 2.

Table 2. Chemical composition and alkali content in CEM I 52.5R wt. \% [25].

\begin{tabular}{llcccccc}
\hline Compound & $\mathrm{CaO}$ & $\mathrm{MgO}$ & $\mathrm{SiO}_{2}$ & $\mathrm{Al}_{2} \mathrm{O}_{3}$ & $\mathrm{Fe}_{2} \mathrm{O}_{3}$ & $\mathrm{SO}_{3}$ & $\mathrm{Na}_{2} \mathrm{O}_{\text {eq }}$ \\
Content & 64.46 & 0.78 & 20.36 & 4.86 & 2.67 & 2.78 & 0.48 \\
\hline
\end{tabular}

- Hydrated lime conformed to the EN 459-1: 2015-06 [27] standard and was characterized by an apparent weight of $390-410 \mathrm{~kg} / \mathrm{m}^{3}$. The chemical composition of lime is given in Table 3.

Table 3. Chemical composition of hydrated lime, wt. \% [25].

\begin{tabular}{cccccc}
\hline Compound & $\mathrm{CaO}$ & $\mathrm{CO}_{2}$ & $\mathrm{SO}_{3}$ & $\mathrm{MgO}$ & Free water \\
Content & 95.5 & 2.1 & 0.1 & 0.5 & 1.5 \\
\hline
\end{tabular}

- $\quad$ Sandstone aggregate - the studies were conducted on the sandstone acquired from Kłodzko Fortress. The chemical composition of the sandstone aggregate was deter- 
mined using the $x$-ray fluorescence method (XRF) and was as follows (\%): $\mathrm{SiO}_{2}-59.92$, $\mathrm{Al}_{2} \mathrm{O}_{3}-17.23, \mathrm{Fe}_{2} \mathrm{O}_{3}-10.74, \mathrm{CaO}-0.29, \mathrm{MgO}-1.4, \mathrm{~K}_{2} \mathrm{O}-3.18$, and $\mathrm{Na}_{2} \mathrm{O}-2.98$. Loss on ignition ranged from 0.74 to 28 (\%). The main properties of the aggregate are presented in Table 4 . The proportion of the grain fraction by weight $\%$ in the mortars is shown in Figure 4.

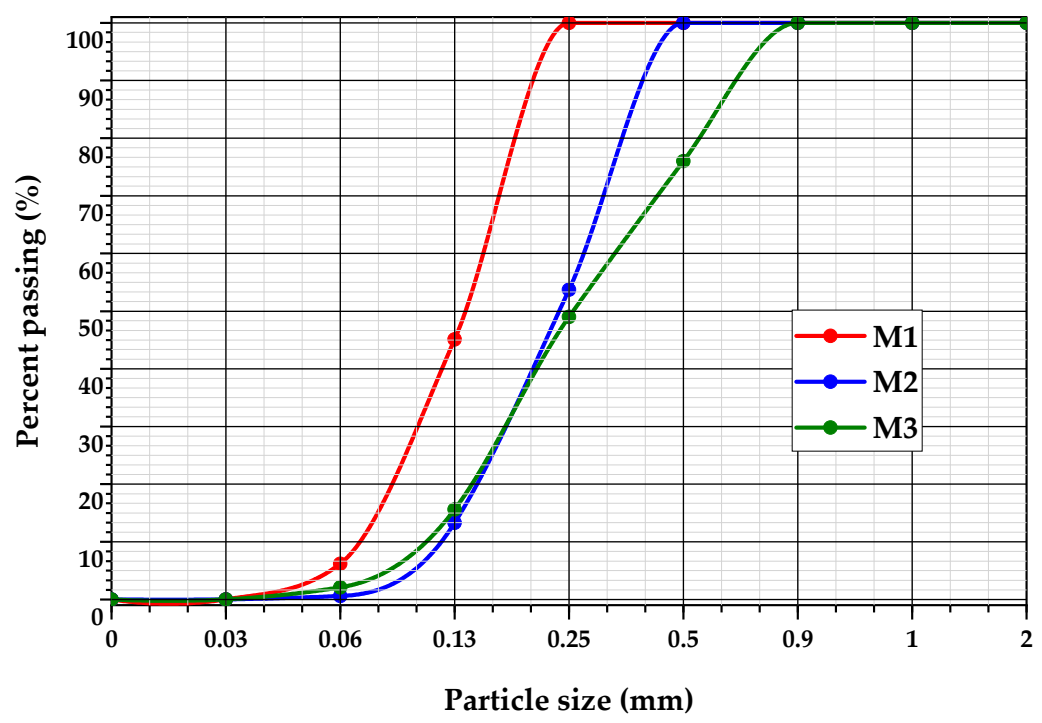

Figure 4. The share of the grain fraction in mass $\%$ in mortars [24].

Table 4. The properties of the sandstone aggregate [24].

\begin{tabular}{|c|c|c|c|}
\hline Bulk density & $\left(\mathrm{g} / \mathrm{cm}^{3}\right)$ & EN 1097-6:2013-11[28] & 2.60 \\
\hline $\mathrm{SD}^{*}$ & & & 0.12 \\
\hline $\mathrm{CV}^{* *}$ & & & 4.72 \\
\hline Porosity & $(\%)$ & PN-EN 1936:2010 [29] & 10.10 \\
\hline $\mathrm{SD}^{*}$ & & & 0.52 \\
\hline $\mathrm{CV}^{* *}$ & & & 5.16 \\
\hline Water absorption & $(\%)$ & EN 13755:2008[30] & 6.37 \\
\hline $\mathrm{SD}^{*}$ & & & 0.27 \\
\hline $\mathrm{CV}^{* *}$ & & & 4.29 \\
\hline Water absorption coefficient & $\left(\mathrm{kg} / \mathrm{m}^{2} \cdot \mathrm{s}^{0.5}\right)$ & EN 1925: 2001[31] & 45.60 \\
\hline $\mathrm{SD} *$ & & & 2.62 \\
\hline $\mathrm{CV}^{* *}$ & & & 5.74 \\
\hline $\begin{array}{c}\text { Compressive strength after } 28 \\
\text { days }\end{array}$ & (MPa) & EN 1926:2001[32] & 37.70 \\
\hline $\mathrm{SD}^{*}$ & & & 3.19 \\
\hline $\mathrm{CV}^{* *}$ & & & 8.47 \\
\hline
\end{tabular}

*SD—standard deviation. ${ }^{* *} \mathrm{CV}$ —coefficient of variation, $(\%)$.

- $\quad$ Methylcellulose hydroxide $-0.15 \%$ addition in all mortars. This admixture enablesgood performance to be achieved; in particular, it improves viscosity, workability, and adhesion of the mortar to the surface. Methylcellulose with a hydrophobic admixture enables mortars to be prepared that are more resistant to dampness [25].

- Copolymer of vinyl acetate-ethylene- $0.9 \%$ addition as a plastifying and strengthening admixture. Addition of the polymer enhances workability and elasticity of the mortar with a beneficial effect on its adhesion. It improves the flexural and compressive strengths as well as adhesion between the binder and aggregate [25].

The sandstone samples were mechanically crushed into smaller pieces. Smaller fractions of the aggregate were prepared by means of a laboratory jaw crusher. Then, particular fractions were obtained through manual sieving. 
Using the particular fractions of sandstone aggregate, sets of samples with the dimensions of $40 \times 40 \times 160 \mathrm{~mm}$ were prepared in line with the EN 196-7:2008 standard [33]. The samples were removed from molds after $24 \mathrm{~h}$, marked on the top surface and placed in a climatic chamber for 21 days at a temperature of $23.5^{\circ} \mathrm{C}$ and humidity of $73.5 \%$, where they remained until the experiments were started.

\subsection{Methods}

The samples were prepared in accordance with the EN 196-7:2008 standard [33]. The samples were deformed after $24 \mathrm{~h}$ and then cured in a humidity chamber at $(20 \pm 2)^{\circ} \mathrm{C}$ and $95 \%$ relative humidity for the remaining 28 days. The studies of the mechanical, physical, and durability properties were performed on hardened mortars after the curing period.

The specific density of mortars was determined with the psychometric method, in line with the PN-EN 1936:2010 standard [29]. Following drying to constant mass at a temperature of $60^{\circ} \mathrm{C}$, the samples were ground in an electric ball mill. The studies involved three samples from each batch of mortar in the amount of $10 \mathrm{~g}$ per sample.

The bulk density of mortars was investigated using the hydrostatic method, according to the EN 1015-10 standard [34]. The studies were performed on six samples from each batch with the dimensions of $40 \times 40 \times 40 \mathrm{~mm}$.

Total porosity was determined in line with the PN-EN 1936:2010 standard [29], expressed in percent as a ratio of pore volume to the sample volume, according to the formula:

$$
p=\left(1-\frac{\rho_{b}}{\rho_{r}}\right) \times 100
$$

where:

$\rho_{b}=$ bulk density, $\left(\mathrm{kg} / \mathrm{m}^{2}\right)$

$\rho_{r}=$ specific density, $\left(\mathrm{kg} / \mathrm{m}^{2}\right)$.

Water absorption by weight was tested according to the PN-B/04500 standard [35]. The value of this parameter was determined on six cubic samples with the edge length of $40 \mathrm{~mm}$. The samples were first saturated in water and then dried to constant mass at a temperature of $60^{\circ} \mathrm{C}$ in order to determine the absorbed water $(\% w / w)$.

Water absorption coefficient $\left(\mathrm{kg} / \mathrm{m}^{2} \cdot \mathrm{s}^{0.5}\right)$, due to capillary rise, was determined in accordance with the EN 1015-18:2002 standard [36]. The investigation was carried out on six samples with the dimensions of $40 \times 40 \times 80 \mathrm{~mm}$. After drying to constant weight, the lateral surfaces were covered with epoxy resin in order to prevent the transportation of water toward the outside. The samples were stored for $24 \mathrm{~h}$ in water at a depth of 5-10 mm. The water absorption coefficient was determined based on the weight of absorbed water.

The compressive and flexural strengths were determined in line with the EN 1015-11:1999 standard [37]. The flexural strength was first determined as an average of three samples of $40 \times 40 \times 160 \mathrm{~mm}$. Then, the halves of samples obtained after the flexural strength test were used in the compressive strength test, in accordance with the EN 1015-11:1999 standard [37]. The surface of the pressure plate was $40 \times 40 \mathrm{~mm}$.

The frost resistance test was performed on six samples with the dimensions of $40 \times 40 \times 40 \mathrm{~mm}$, according to the PN-88/B-06250 standard [38]. The samples were frozen in air, at a temperature of $(-20 \pm 2)^{\circ} \mathrm{C}$ for $4 \mathrm{~h}$, and then thawed in water at $(20 \pm 2){ }^{\circ} \mathrm{C}$ for $2 \mathrm{~h}$. In total, the test was carried out in 25 cycles. Following the investigation, the samples were dried to constant weight and weighted in order to determine the weight loss.

The resistance to salt crystallization was determined as the average loss in mass of six cubic samples with a $40 \mathrm{~mm}$ side, in line with the EN 12370:1999 standard [39]. Following drying to constant weight, the samples were stored submerged in $14 \% \mathrm{Na}_{2} \mathrm{SO}_{4}$ solution for $2 \mathrm{~h}$, and then the samples were dried at a temperature of $60^{\circ} \mathrm{C}$ for at least $10 \mathrm{~h}$. The test consisted of 15 cycles. Afterward, the samples were placed in water for $24 \mathrm{~h}$ and dried to constant mass. 


\section{Results and Discussion}

The properties of the mortar used for filling stone should be comparable to the parent rock, but with lower durability [40]. It is important that the mortar have a similar appearance, color, and grain to the stone. Hardened renovation mortar should be characterized by comparable or lower durability than stone as well as high resistance to frost and harmful substances crystallizing in the pores of the material. In order to ensure appropriate transportation of moisture from the repaired surface, the mortar should be characterized with higher capillary absorption to absorb moisture and salt solutions. Simultaneously, high permeability should be ensured [41].

Tables 5 and 6 and Figure 5 present the physical properties of renovation mortars for sandstone reconstruction.

Table 5. The physical properties of mortars.

\begin{tabular}{cccc}
\hline & Bulk Density & Specific Density & Total Porosity \\
\hline & $\left(\mathrm{g} / \mathrm{cm}^{3}\right)$ & $\left(\mathrm{kg} / \mathrm{m}^{3}\right)$ & $(\%)$ \\
\hline $\mathrm{M} 1$ & 1.58 & 2560 & 39.1 \\
$\mathrm{SD}^{*}$ & 0.07 & 0.02 & 2.78 \\
$\mathrm{CV}^{* *}$ & 4.82 & 0.59 & 6.59 \\
$\mathrm{M} 2$ & 1.88 & 2450 & 25.0 \\
$\mathrm{SD}^{*}$ & 0.02 & 0.01 & 0.90 \\
$\mathrm{CV}^{* *}$ & 1.54 & 0.37 & 2.17 \\
$\mathrm{M}^{*}$ & 1.67 & 2510 & 31.1 \\
$\mathrm{SD}^{*}$ & 0.01 & 0.01 & 0.40 \\
$\mathrm{CV}^{* *}$ & 0.71 & 0.43 & 0.96 \\
\hline
\end{tabular}

*SD—standard deviation. ** CV—coefficient of variation, $(\%)$

Table 6. Water absorptivity values and water absorption coefficient for the reconstruction mortars.

\begin{tabular}{ccc}
\hline & Water Absorptivity & Water Absorption Coefficient \\
\hline & $(\%)$ & $\left(\mathrm{kg} / \mathrm{m}^{2} \cdot \mathrm{s}^{0.5}\right)$ \\
\hline $\mathrm{M} 1$ & 34.5 & 73.85 \\
$\mathrm{SD}^{*}$ & 0.55 & 0.58 \\
$\mathrm{CV}^{* *}$ & 1.58 & 4.39 \\
$>\mathrm{M} 2$ & 24.3 & 43.20 \\
$\mathrm{SD}^{*}$ & 1.09 & 0.46 \\
$\mathrm{CV}$ & 3.22 \\
$\mathrm{M}^{* *}$ & 4.49 & 11.63 \\
$\mathrm{SD}^{*}$ & 28.0 & 0.29 \\
$\mathrm{CV}^{* *}$ & 0.48 & 1.70 \\
\hline
\end{tabular}

*SD—standard deviation, ${ }^{* *} \mathrm{CV}$-coefficient of variation, $(\%)$.

The fine-grained M1 mortars were characterized by the highest specific density. These mortars exhibited the lowest apparent density and highest total porosity. The mortars with the highest apparent density (i.e., M2) turned out to be least porous from the investigated mortars. Due to the detrimental effect of water on stone, the appropriate pore structure of the reconstruction mortar is important. The capacity for water vapor transportation should be higher or equal to that of the stone, in order to enable faster removal of water from the inside of the stone [11]. It should be remembered that along with the increasing amount of cement in the cement-lime mortar, the material porosity decreases [42]. 


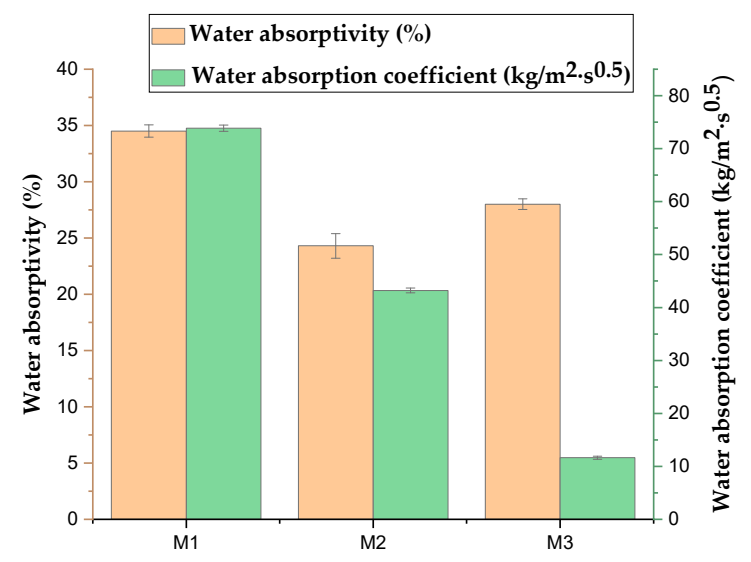

Figure 5. Water absorptivity and water absorption coefficient of mortars.

Z. Pavlík et al. [43] showed that replacing natural aggregate with sandstone aggregate in the amount of $25 \%$ of the aggregate mass reduced the porosity of cement mortars by $2 \%$ compared to the reference mortars.

The water absorption by weight of the considered mortars ranged from 24.3 to 34.5 (\%), whereas the water absorption coefficient was in the range from 11.63 to $73.85\left(\mathrm{~kg} / \mathrm{m}^{2} \cdot \mathrm{s}^{0.5}\right)$. The highest capillary absorption was achieved by fine-grained mortars M1 with the water absorption coefficient of $73.85\left(\mathrm{~kg} / \mathrm{m}^{2} \cdot \mathrm{s}^{0.5}\right)$. Higher capillary absorption of mortars in relation to stone allows for harmful substances to be accumulated in their pores, rather than in stone [44], which protects it against the negative impact of salts contained in water. Higher water absorptivity is connected with a high porosity of mortars. This dependence is shown in Figure 6.

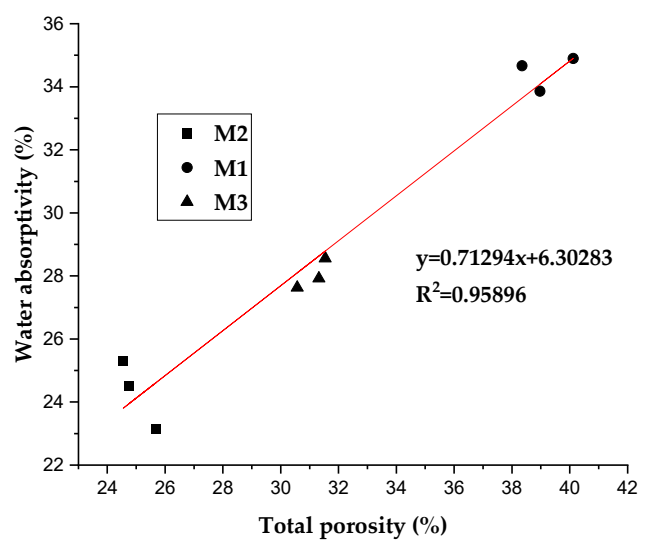

Figure 6. The dependence of water absorptivity on the total porosity of renovation mortars.

The highest water absorption by weight, equal to $34.5 \%$, was achieved by fine grained M1 mortars. The obtained results indicate that the application of fine-grained aggregate in the reconstruction mortars increases their water absorptivity and porosity. This was confirmed in the studies on the mortars with white cement conducted by Brycki W. et al. $[45,46]$. The authors in [45] investigated the basic properties of various types of mortars with aggregate containing Lgota, Godula, and Istebna sandstone with medium-, fine-, and uniform grain size. The fine-grained aggregate from the Godula sandstone increased the capillary absorption of mortars more than twice, in relation to the medium-grained mortar. This dependence was confirmed by further studies of Brycki W. et al. [46]. The fine-grained mortars with limestone aggregate exhibited $20 \%$ higher water absorptivity than the coarse-grained aggregate, simultaneously achieving $11 \%$ greater compressive strength. 
Similar conclusions were also drawn by Domasłowski W. [41], who examined mortars with fine-grained aggregate from crushed Gotland and Obernkirchen sandstones. The investigated mortar with white cement exhibited twice higher water absorption by weight in relation to the mortar with quartz sand. Table 7 presents the mechanical properties and durability of the designed renovation mortars.

Table 7. The mechanical properties and durability of renovation mortars.

\begin{tabular}{ccccc}
\hline & $\begin{array}{c}\text { Flexural } \\
\text { Strength }\end{array}$ & $\begin{array}{c}\text { Compressive } \\
\text { Strength }\end{array}$ & $\begin{array}{c}\text { Frost Resistance } \\
(-) \text { Weight Loss }\end{array}$ & $\begin{array}{c}\text { Salt Crystallization } \\
(+/-) \text { Weight } \\
\text { Difference }\end{array}$ \\
\hline M1 & $\mathbf{( M P a )}$ & $\mathbf{( M P a )}$ & $\mathbf{( \% )}$ & $\mathbf{( \% )}$ \\
$\mathrm{SD}^{*}$ & 2.27 & 5.69 & 0.30 & +4.78 \\
$\mathrm{CV}^{* *}$ & 0.731 & 0.37 & 0.27 & 1.18 \\
$\mathrm{M}^{*}$ & 21.19 & 6.55 & 48.84 & 24.79 \\
$\mathrm{SD}^{*}$ & 2.91 & 6.98 & 0.29 & +2.96 \\
$\mathrm{CV}$ & 0.47 & 0.43 & 0.07 & 1.29 \\
$\mathrm{M}^{*}$ & 16.25 & 6.14 & 22.47 & 43.62 \\
$\mathrm{SD}^{*}$ & 1.58 & 3.72 & 0.30 & +3.51 \\
$\mathrm{CV}^{* *}$ & 0.63 & 0.36 & 0.07 & 0.62 \\
\hline
\end{tabular}

* SD—standard deviation. ${ }^{* *} \mathrm{CV}$ - coefficient of variation, (\%).

The compressive strength of the renovation mortar should be lower than that of stone. The mortars achieved compressive strength in the range of 3.72-6.98 (MPa). These values were lower than the tested sandstone, the compressive strength of which was $37.70 \mathrm{MPa}$. The tensile strength of the mortars while bending was in the range of 1.58-2.98 (MPa).The lowest compressive and bending strength was demonstrated by mortars with coarse aggregate. Miranda L.F.R et al. [47] claim that coarse aggregates create weaker bonds between the aggregate and the slurry, which results in a reduction of the compressive strength of mortars [40].In the case of fine-grained aggregates, the durability of interfacial bond significantly depends on the surface porosity of crushed aggregate [48].

The edge shape of the recycled aggregate particles is responsible for the increase in compressive strength, contributing to the improvement in the strength of the transition zone between the aggregate and the cement slurry as a result of aggregate interlocking. Similar conclusions were obtained by Corinaldesi V. et al. [49]. However, P. Quiroga et al. [50] noticed that the aggregate obtained by crushing rocks, having an angular shape, combined with the cement slurry, causing a decrease in workability. This resulted in an increased demand for water, which in turn reduced the compressive strength of the mortar. In order to avoid this, it is necessary to select the appropriate $\mathrm{w} / \mathrm{c}$ ratio in mortars with recycled aggregate or to use suitable fluidizing admixtures. The positive effect of recycled aggregate on the strength of cement mortars and concretes has been confirmed by many studies available in the literature [43,49-52]. Pavlik et al. [43] observed that replacing 25\% of natural sand with sandstone aggregate increased the compressive and bending strength of mortars by 15 and 4 (\%), respectively, compared to the reference samples. The studies conducted by Sanjay Mundra M. et al. [51] on concrete with aggregate from sandstone waste showed that the highest compressive strength was achieved by the cement composites with fine-grained sandstone aggregate in the amount of $30 \%$ with a w/c ratio of 0.4 and 0.45 . The authors attributed the increase in strength to a favorable hydration mechanism by creating a homogeneous and dense matrix structure between the aggregate and the slurry. On the other hand, the Prasetia-Maulan team [52] reported that the compressive strength of the mortar measured after 28 days increased along with the amount of waste. The complete replacement of natural river sand with stone waste at a w/c ratio of 0.5 increased the average compressive strength by as much as $80 \%$ compared to the sample without waste aggregate. All tested mortars were characterized by a low ratio of compressive strength to tensile strength $\left(\mathrm{f}_{\mathrm{cm}} / \mathrm{f}_{\mathrm{fm}}\right)$. This means that the mortars based on lime binder showed elastic 
properties corresponding to a low modulus of elasticity. This was proven in the studies of Bricolo-Rovero syndrome [53]. Stefanidou M. et al. [54], comparing mortars with natural sand and recycled sand with various binders, found that sand of recycled origin improved the compressive strength of mortars on lime and lime-pozzolanic binders, in contrast to natural sand with cement binders. This is due to the reaction between the lime and the silica Al-Si components of the aggregate.

Higher durability was obtained than that in limestone mortars, which was possible due to the addition of white cement as well as a copolymer of vinyl acetate-ethylene to the binder. White cement was characterized by high compressive strength and stability, whereas its aesthetic value stemming from the white color contributes to its widespread application as a component of plastering mixes, architectural elements, and renovation mortars [42].

The addition of cement to the limestone mortar in an amount lower than $40 \%$ slightly improved the compressive strength and accelerated the binding process, having no significant effect on the mortar plasticity [55]. In turn, the strengthening admixture corresponding to the copolymer of vinyl acetate-ethylene in the amount of $0.9 \%$ cement weight successfully improved the compressive and flexural strength of mortars [25].

All three types of mortars turned out to be frost-resistant, achieving a weight loss after 25 freeze-thaw cycles in the range of 0.29-0.3 (\%). Pictures of random mortar samples after frost resistance testing are presented in Figure 7 . The photos clearly show no external damage, cracks, and cavities.

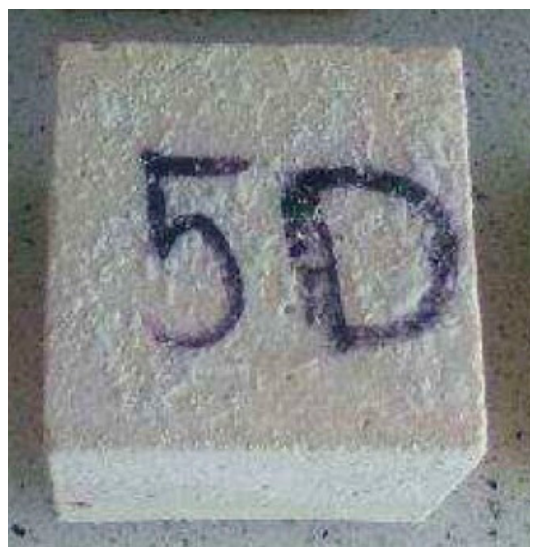

M1

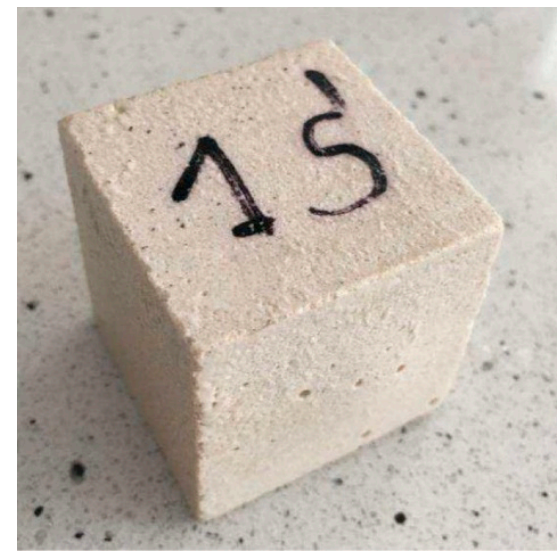

M2

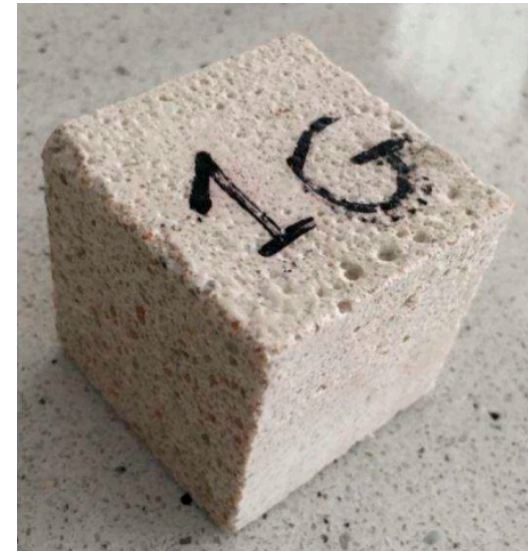

M3

Figure 7. Renovation mortars following the frost resistance test.

The frost resistance is affected by the granulometry and total porosity of the mor$\operatorname{tar}[54,56]$. Moreover, Von Konow T. [57] explains that fine-grained aggregates increase the Aggregate Index (AI), whereas coarse-grained aggregates lower it. The aggregates with high AI are characterized by low modulus of elasticity and high frost resistance.

The studied renovation mortars indicated increased weight following the salt crystallization test. This means that a significant part of the salts from the $\mathrm{Na}_{2} \mathrm{SO}_{4}$ solution crystallized in the pores of the mortar without causing any damage. High resistance to salt crystallization is caused by high porosity of the limestone-cement mortars. The dependence of the weight of crystallized salts on total porosity is presented in Figure 8 . The M2 mortars with lower porosity indicated the lowest weight increase following the salt crystallization resistance test, whereas the greatest amount of salt crystallized in the M1 mortars with the highest porosity. 


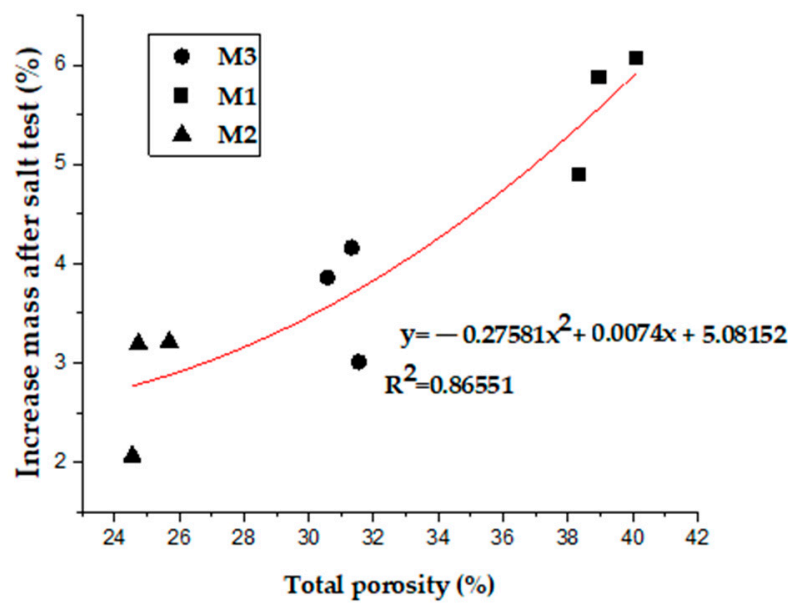

Figure 8. Dependence of weight increase after the salt crystallization test on total porosity.

Barnat-Hunek D. et al. [25] indicated a positive effect related to the copolymer of vinyl acetate-ethylene on lowering the porosity and water absorptivity of mortars and increase of durability. A decrease in weight loss following the frost resistance test and salt crystallization test was observed, reaching 52 and $23 \%$, respectively, in relation to the non-modified samples.

The cement-limestone mortars were more resistant to sulfate salts than pure limestone mortars; therefore, the samples were not completely destroyed in the $\mathrm{Na}_{2} \mathrm{SO}_{4}$ solution. Similar conclusions were drawn by Winnefeld F. et al. [58]. In turn, Gulbe L. et al. [56] observed that the resistance to salt crystallization increased along with the cement content in the limestone-cement mortars. While the samples with 2 and 4 (\%) cement content indicated a weight loss following 12 cycles of sulfate resistance test, the mortars with 8 and $10(\%)$ cement content showed no change in weight. Increased content of cement also had a beneficial effect on the frost resistance of the limestone-cement mortars. The mortars with 2 and 4 (\%) cement content were completely destroyed after 10 freezing and thawing cycles; in contrast, the samples with a higher cement content were intact and showed no weight loss.

\section{Conclusions}

The studies concerning the possibility of using mortars with recycled stone aggregate for the reconstruction of sandstone in historic buildings. The following conclusions were drawn:

- $\quad$ application of fine-grained aggregate from crushed sandstone improved total porosity and absorptivity of the limestone-cement mortars by 36 and 42 (\%), respectively, compared to the medium-grained mortar;

- $\quad$ the medium-grained mortars with lower porosity were characterized by the highest apparent density;

- $\quad$ the coarse-grained mortars exhibited the lowest water absorption coefficient, equal to $11.63\left(\mathrm{~kg} / \mathrm{m}^{2} \cdot \mathrm{s}^{0.5}\right)$. This result is over 6 -fold lower than the value achieved by fine-grained mortars;

- $\quad$ the highest compressive and flexural strengths were obtained by medium-grained M2 mortars. Application of the finer aggregate improved the compressive strength by $88 \%$, compared to the coarse-grained M3 mortar. High strength was achieved through the application of white cement as well as the ethylene and vinyl acetate co-polymer;

- $\quad$ all examined mortars were resistant to frost and salt crystallization, with no substantial weight loss.

The application of sandstone aggregate in mortars as a substitute for natural aggregates increases the contribution of conservators in preserving sustainable environment and ecology in the world. In terms of environmental protection, application of fine-grained 
recycled aggregates has the following advantages: it minimizes sand mining, energy consumption, and $\mathrm{CO}_{2}$ emissions as well as prevents illegal deposits and storage of debris.

Sandstone is a highly diversified type of rock in terms of grain size and chemical composition. Therefore, investigating mortars with different grain sizes is essential for designing compatible renovation mortars. In the case of the sandstones examined in this study, the most compatible mortar was medium-grained M2, with the lowest absorptivity and highest durability. This mortar was also resistant to frost and salt crystallization. The next stage of research on mortars will be connected with field studies performed directly on the investigated object.

Author Contributions: Conceptualization, B.K.; Methodology, B.K.; Formal analysis, M.G.-F.; Investigation, B.K.; Writing-original draft preparation, B.K. and M.G.-F.; Writing-review and editing, M.G.-F.; Supervision, B.K.; Project administration, B.K.; Funding acquisition, B.K. Both authors have read and agreed to the published version of the manuscript.

Funding: This work was financially supported by the Ministry of Science and Higher Education, within the 389 statutory, research number FN/61/AU/2020.

Institutional Review Board Statement: Not applicable.

Informed Consent Statement: Not applicable.

Data Availability Statement: Not applicable.

Conflicts of Interest: The authors declare no conflict of interest.

\section{References}

1. Apostolopoulou, M.; Aggelakopoulou, E.; Bakolas, A.; Moropoulou, A. Compatible Mortars for the Sustainable Conservation of Stone in Masonries. In Advanced Materials for the Conservation of Stone; Springer: Cham, Switzerland, 2018; pp. 97-123.

2. Franzoni, E.; Sassoni, E. Correlation between microstructural characteristics and weight loss of natural stones exposed to simulated acid rain. Sci. Total Environ. 2011, 412-413, 278-285. [CrossRef] [PubMed]

3. Groot, C.J.W.P.; Gunneweg, J.T.M. Choosing mortar compositions for repointing of historic masonry under severe environmental conditions. In Hist. Mortars, Springer International; Hughes, J.J., Válek, J., Groot, C.J.W.P., Eds.; Springer: Cham, Switzerland, 2019; pp. 143-154.

4. Cardell, C.; Benavente, D.; Rodríguez-Gordillo, J. Weathering of limestone building material by mixed sulfate solutions. Characterization of stone microstructure, reaction products and decay forms. Mater. Charact. 2008, 59, 1371-1385. [CrossRef]

5. Krzywobłocka-Laurów, R. Koncepcja oceny stanu kamiennych obiektów zabytkowych. Ochr. Zabyt. 1998, 51, 31-34.

6. Schueremans, L.; Cizer, Ö.; Janssens, E.; Serré, G.; Balen, K.V. Characterization of repair mortars for the assessment of their compatibility in restoration projects: Research and practice. Constr. Build Mater. 2011, 25, 4338-4350. [CrossRef]

7. Delgado Rodrigues, J.; Grossi, A. Indicators and ratings for the compatibility assessment of conservation actions. J. Cult. Herit. 2007, 8, 32-43. [CrossRef]

8. Torney, C.; Forster, A.M.; Banfill, P.F.G.; Szadurski, E.M. The effects of site practice on the physical properties of proprietary stone restoration mortar. Constr. Build. Mater. 2015, 75, 359-367. [CrossRef]

9. Pavia, S.; Brennan, O. Portland cement-lime mortars for conservation. In Hist. Mortars; Hughes, J.J., Válek, J., Groot, C.J.W.P., Eds.; Springer International: Berlin/Heidelberg, Germany, 2019; pp. 129-142.

10. Torney, C.; Forster, A.M.; Kennedy, C.J.; Hyslop, E.K. Plastic repair of natural stone in Scotland: Perceptions and practice. Struct. Surv. 2012, 30, 297-311. [CrossRef]

11. Klisinska-Kopacz, A.; Tislova, R.; Adamski, G.; Kozlowski, R. Pore structure of historic and repair roman cement mortars to establish their compatibility. J. Cult. Herit. 2010, 1, 404-410. [CrossRef]

12. Papayianni, I.; Pachta, V.; Stefanidou, M. Analysis of ancient mortars and design of compatible repair mortars: The case study of Odeion of the archaeological site of Dion. Constr. Buildins Mater. 2013, 40, 84-92. [CrossRef]

13. Silva, B.A.; Pinto, A.P.F.; Gomes, A. Natural hydraulic lime versus cement for blended lime mortars for restoration works. Constr. Build. Mater. 2015, 94, 346-360. [CrossRef]

14. Aggelakopoulou, E.; Bakolas, A.; Moropoulou, A. Properties of lime-metakolin mortars for the restoration of historic masonries. Appl. Clay Sci. 2011, 53, 15-19. [CrossRef]

15. Ventola, L.; Vendrell, M.; Giraldez, P.; Merino, L. Traditional organic additives improve lime mortars: New old materials for restoration and building natural stone fabric. Constr. Build. Mater. 2011, 25, 313-318. [CrossRef]

16. Lopez-Arce, P.; Tagnit-Hammou, M.; Menendez, B.; Mertz, J.D.; Guiavarc'h, M.; Kaci, A.; Aggoun, S.; Cousture, A. Physicochemical stone-mortar compatibility of commercial stone-repair mortars of historic buildings from Paris. Constr. Build. Mater. 2016, 124, 424-441. [CrossRef] 
17. Iucolano, F.; Liguori, B.; Caputo, D.; Colangelo, F.; Cioffi, R. Recycled plastic aggregate in mortars composition: Effect on physical and mechanical properties. Mater. Des. 2013, 52, 916-922. [CrossRef]

18. Tencati, A.; Poguts, S.; Romero, C. Achieving Environmental Sustainability. In The Future International Manager: A Vision of the Roles and Duties of Management, 1st ed.; Zsolnai, L., Tencati, A., Eds.; Palgrave Macmillan: London, UK, 2009 ; pp. $23-48$.

19. Benabed, B.; Soualhi, H.; Ase, B.; Azzouz, L.; Kadri, E.; Kenai, S. Effect of limestone powder as a partial replacement of crushed quarry sand on properties of self-compacting repair mortars. J. Build. Mater. Struct. 2016, 3, 15-30.

20. Puzo-Antonio, J.S. Evolution of mechanical properties and drying shrinkage in lime-based and lime cement-based mortars with pure limestone aggregate. Constr. Build. Mater. 2015, 77, 472-478. [CrossRef]

21. Galetakis, M.; Alevizos, G.; Leventakis, K. Evaluation of fine limestone quarry by-products, for the production of building elements-An experimental approach. Constr. Build. Mater. 2012, 26, 122-130. [CrossRef]

22. Salah Nasr, M.; Shubbar, A.A.; Al-AbideenRaed Abed, Z.; Ibrahim, S.M. Properties of eco-friendly cement mortar contained recycled materials from different sources. J. Build. Eng. 2020, 31, 101444. [CrossRef]

23. Bukal, G. Twierdza Kłodzko w ujęciu historycznym. In Fortyfikacja, 12th ed.; Polish Committee for Standardization: Warsaw, Poland, 2000.

24. Klimek, B. The problem of repairing the stone facades on an example of Donjon fortress Kłodzko. In Current Issues in Research, Conservation and Restoration of Historic Fortifications, 9th ed.; Grudziński, Z., Bevs, M., Eds.; Polytechnic National University: Lviv, Ukraine, 2017; pp. 113-122.

25. Barnat-Hunek, D.; Siddique, R.; Klimek, B.; Franus, M. The use of zeolite, lightweight aggregate and boiler slag in restoration renders. Constr. Build. Mater. 2017, 142, 162-174. [CrossRef]

26. EN 197-1:2011. Cement_Part 1: Composition, Specifications and Conformity Criteria for Common Cements; European Committee for Standardization: Brussels, Belgium, 2011.

27. EN 459-1:2015-06. Building Lime-Part 1: Definitions, Requirements and Compatibility Criteria; European Committee for Standardization: Brussels, Belgium, 2015.

28. EN 1097-6: 2013-11. Tests for Mechanical and Physical Properties of Aggregates_Part 6: Determination of Particle Density and Water Absorption; European Committee for Standardization: Brussels, Belgium, 2013.

29. PN EN 1936:2010. Natural Stone Test Methods-Determination of Real Density and Apparent Density, and of Total and Open Porosity; Polish Committee for Standardization: Warsaw, Poland, 2010.

30. EN 13755:200. Natural Stone Test Methods—Determination of Water Absorption at Atmospheric Pressure; European Committee for Standardization: Brussels, Belgium, 2008.

31. EN 1925: 1999. Natural Stone Test Methods-Determination of Water Absorption coefficient by Capillarity; European Committee for Standardization: Brussels, Belgium, 1999.

32. EN 1926:2001. Natural Stone Test Methods—Determination of Uniaxial Compressive Strength; German Institute for Standardisation: Brussels, Belgium, 2007.

33. EN 196-7:2008. Methods of Testing Cement_Part 7: Methods of Taking and Preparing Samples of Cement; European Committee for Standardization: Brussels, Belgium, 2008.

34. EN 1015-10:1999. Methods of Test for Mortar for Masonry_Part 10: Determination of Dry Bulk Density of Hardened Mortar; European Committee for Standardization: Brussels, Belgium, 1999.

35. PN-85/B-04500. Building Mortars-Testing of Physical and Mechanical Properties (in Polish); Polish Committee for Standardization: Warsaw, Poland, 1985.

36. EN 1015-18:2002. Methods of Test for Mortar for Masonry_Part 18: Determination of Water Absorption Coefficientdue to Capillarity Action of Hardened Mortar; European Committee for Standardization: Brussels, Belgium, 2002.

37. EN 1015-11:1999. Methods of Test for Mortar for Masonry_Part 11: Determination of Flexural and Compressive Strength of Hardened Mortar; European Committee for Standardization: Brussels, Belgium, 1999.

38. PN-88/B-06250. Ordinary Concrete (in Polish); Polish Committee for Standardization: Warsaw, Poland, 1988.

39. EN12370:1999. Natural Stone Test Methods_-Determination of Resistance to Salt Crystallization; European Committee for Standardization: Brussels, Belgium, 1999.

40. Isebaert, A.; Van Parys, L.; Cnudde, V. Composition and compatibility requirements of mineral repair mortars for stone-A review. Constr. Build. Mater. 2014, 59, 39-50. [CrossRef]

41. Domasłowski, W. Research on the Technology of Mortars Imitating Gotland and Obernkirchen Natural Stones; Historic Studies and Conservation 39: Torun, Poland, 2010.

42. Arandigoyen, M.; Alvarez, J.I. Blended pastes of cement and lime: Pore structure and capillary porosity. Appl. Surf. Sci. 2006, 252, 8077-8085. [CrossRef]

43. Pavlík, Z.; Záleská, M.; Pokorný, J.; Pavlíková, M.; Jankovský, O. Study on the possible use of sandstone dust as fine Aggregate in mortar mix desig, Green Buildings Technologies and Material. In Proceedings of the 8th International Multidisciplinary Scientific GeoConference SGEM, Albena, Bulgaria, 2-8 July 2018.

44. Smoleńska, A.; Rembiś, M. Charakter zniszczeń piaskowca użytego w zabytkowych kapliczkach w Tychach pod kątem ich rekonstrukcj. Ochr. Zabyt. 2011, 5, 360-365.

45. Brylicki, W.; Łagosz, A.; Smoleńska, A.; Rembiś, M. Właściwości zapraw mineralnych do rekonstrukcji piaskowców w obiektach zabytkowych. Cem. Wapno Beton 1999, 2, 52-57. 
46. Smoleńska, A.; Rembiś, M.; Brylicki, W.; Małolepszy, J.; Łagosz, A. Environment Friendly Filling Compound for Use in Reconstruction of Monumental Buildings. Patent No. PL 191390 B1, 12 March 1999.

47. Miranda, L.F.R.; Selmo, S.M.S. CDW Recycled Aggregate Renderings: Part I-Analysis of the Effect of Materials Finer than $75 \mu \mathrm{m}$ on Mortar Properties. Constr. Build. Mater. 2006, 209, 615-629. [CrossRef]

48. Caliskan, S.; Karihaloo, B.L. Effect of surface roughness, type and size of model aggregates on the bond strength of aggregate/mortar interface. Interface Sci. 2004, 12, 361-374. [CrossRef]

49. Corinaldesi, V.; Moriconi, G. Behaviour of cementitious mortars containing different kinds of recycled aggregate. Constr. Build. Mater. 2009, 23, 289-294. [CrossRef]

50. Quiroga, P.; Fowler, D. The Effects of Aggregates Characteristics on the Performance of Portland Cement Concrete; Project No. ICAR 104-1F; International Center for Aggregates Research; University of Texas: Austin, TX, USA, 2004; pp. 13-26.

51. Mundra, S.M.; Agrawal, V.; Nagar, R. Sandstone cutting waste as partial replacement of fine aggregates in concrete: A mechanical strength perspective. J. Build. Eng. 2020, 32, 101534. [CrossRef]

52. Prasetia, I.; Maulana, A. Effects of crushed stone waste as fine aggregate on mortar and concrete properties. IOP Conf. Ser. Mater. Sci. Eng. 2009, 620, 012040. [CrossRef]

53. Briccoli, B.S.; Rovero, L. Gliadditivi per Malteusatinell' Antichita. Available online: https://flore.unifi.it/handle/2158/17469\#. YA6SPBYRVhE (accessed on 23 January 2021).

54. Stefanidou, M.; Anastasiou, E.; GeorgiadisFilikas, K. Recycled sand in lime-based mortars. Waste Manag. 2014, 34, 2595-2602. [CrossRef]

55. Moresová, K.; Škvára, F. White cement-Properties, manufacture, prospects. Ceramics 2001, 45, 158-163.

56. Gulbe, I.; Vitina, I.; Setina, J. The Influence of Cement on Properties of Lime Mortars. Procedia Eng. 2017, 172, 325-332. [CrossRef]

57. Von Konow, T. Aggregate grain size distribution-A major influence on many properties of lime mortars for restoration. In EUROMAT 2003, Symposium P2-Materials and Conservation of Cultural Heritage; EPFL: Lausanne, Switzerland, 2003; 9p.

58. Winnefeld, F.; Böttger, K.G. How clayey fines in aggregated influence the properties of lime mortars. Mater. Struct. 2006, 39, 433-443. [CrossRef] 